\title{
Phosphate adsorption characteristics of two soils responding differently to $\mathbf{P}$ fertilization
}

\author{
MARKKU YLI-HALLA \\ Kemira Oy, Espoo Research Centre, Luoteisrinne 2, \\ SF-02270 ESPOO, Finland
}

\begin{abstract}
The soil samples of the present study originated from two field experiments in which five rates of $\mathrm{P}$ (annually 0,13 or 16, 26 or 32,47 or 56,60 or $72 \mathrm{~kg} \mathrm{P} / \mathrm{ha}$ ) had been applied for 11 or 12 years. The fields were silty clay soils (Cryochrepts) not differing markedly in $\mathrm{pH}$, contents of clay, organic $\mathrm{C}$, or poorly crystalline $\mathrm{Al}$ and $\mathrm{Fe}$ oxides. Before the field experiment, the quantities of $\mathrm{P}$ extracted with an ammonium acetate solution ( $\mathrm{pH} 4.65$ ) were approximately $6 \mathrm{mg} / \mathrm{dm}^{3}$ in both fields. However, the fields differed considerably in the response of the crop to $\mathrm{P}$ fertilization. Phosphorus adsorption by the soil samples was studied by shaking the samples in solutions of different $\mathrm{P}$ concentrations $(0-0.5 \mathrm{mg} / \mathrm{l})$. Soil $\mathrm{I}$, showing greater response to $\mathrm{P}$ fertilization in the field, adsorbed $\mathrm{P}$ considerably more effectively than did soil II. Also the quantities of reversibly adsorbed $\mathrm{P}$ were smaller in the subsamples of soil I as compared to those of soil II receiving the same fertilization. Fertilizer P applied during the field experiments had been adsorbed and converted to forms unavailable to plants to a larger extent in soil I, resulting in greater response to $\mathrm{P}$ fertilization in this soil. The difference in response to applied $\mathrm{P}$ or in residual effect of $\mathrm{P}$ fertilization could not be predicted from soil characteristics other than P sorption.
\end{abstract}

Index words: adsorption isotherms, mineral soils, reversibly adsorbed $\mathrm{P}$

\section{Introduction}

Single extractions with e.g. water or an ammonium acetate solution have rather successfully been used for predicting yield responses to $\mathrm{P}$ fertilization of cereal crops in Finland (e.g. Sippola and SaArela 1986). The results obtained with these methods give an index for the reserves of plant-available $\mathrm{P}$ at the time of sampling and for $\mathrm{P}$ fertilization requirement in that year. The residual effect of $\mathrm{P}$ fertilization cannot, however, be predicted by ordinary soil testing methods prior to fertilizer application, because individual soils differ greatly in the rate of $\mathrm{P}$ fixation. For example, in 18 mineral soils of England, a large application of superphosphate lost half of its fertilizer value over a period of one to six years 
(LARSEN et al. 1965). This phenomenon results at least to some extent in an unpredictable duration of fertilization effect of added $P$.

This study deals with soil samples taken from two long-term field experiments in which, despite the initially same fairly low level of easily soluble P, a different response by cereal crops to $\mathrm{P}$ fertilization was observed (Yli-Halla 1989b). In one experiment, no statistically significant response was observed until the eighth year, while in the other one, substantial response was measured already in the first experimental year. Further, more P was extracted with water or an ammonium acetate solution at the end of the field experiments from soil samples taken from the field less responsive to $\mathrm{P}$ fertilization. Yet, the experimental fields did not differ considerably in the contents of clay, organic matter, poorly crystalline $\mathrm{Al}$ and $\mathrm{Fe}$ oxides or $\mathrm{pH}$.

In the present study, the soils of these two experiments were examined in more detail in order to find out an explanation for the different yield responses to $\mathrm{P}$ fertilization in the experimental fields. Adsorption-desorption isotherms for phosphate were determined and the soils were analyzed for reversibly adsorbed $\mathrm{P}$.

\section{Materials and methods}

The soil material consisted of samples taken from the unlimed plots of two field experiments in which five rates of $P$ fertilization $(0$, 13 or 16,26 or 32,47 or 56 , and 60 or $72 \mathrm{~kg}$ $\mathrm{P} / \mathrm{ha}$ ) had been applied annually for 12 years (soil I; four blocks, 20 samples) or for 11 years (soil II; three blocks, 15 samples). The experimental fields, located in Vihti, Southern Finland, were silty clay soils and, according to the U.S. Soil Taxonomy, tentatively classified as Cryochrepts. The experimental design, soil characteristics as well as the results of the field experiments, in which mainly cereal crops were cultivated, have been reported earlier (Yli-Halla 1989b). In that previous paper, soils I and II were referred to as experiments A and B, respectively. Some properties of the experimental soils are summarized in Table 1.

Isotherms for phosphate adsorption and desorption were determined according to the method by Hartikainen (1982b). Duplicate soil samples $(1.0 \mathrm{~g})$ were equilibrated for 23 hours in $50 \mathrm{ml}$ of solution containing different concentrations $(0.01,0.02,0.05,0.10$, $0.20,0.30,0.40$, or $0.50 \mathrm{mg} \mathrm{P} / \mathrm{l})$ of $\mathrm{P}$ as $\mathrm{KH}_{2} \mathrm{PO}_{4}$ in centrifuge tubes. No supporting electrolyte was used. After adding the solution, the suspensions were shaken for $1 \mathrm{~h}$ and allowed to stand for $22 \mathrm{~h}$ and then shaken again for $10 \mathrm{~min}$. The suspensions were centrifuged, and the supernatant solutions were decanted and filtered through a membrane filter (pore size $0.2 \mathrm{um}$ ) and analyzed for $\mathrm{P}$ by a molybdate blue method using ascorbic acid as the reducing agent (ANON. 1969). The quantities of $\mathrm{P}$ adsorbed or desorbed $(\mathrm{y})$ were plotted against the initial $\mathrm{P}$ concentration ( $\mathrm{x}$ ) of the added solution (isotherm A) or against the $\mathrm{P}$ concentration of the supernatant solution (isotherm B). The quantities of $\mathrm{P}$ adsorbed or desorbed were expressed as milligrams per kilogram of soil and the solu-

Table 1. Some chemical and physical characteristics of the experimental soils.

\begin{tabular}{llccccc}
\hline Soil & \multicolumn{1}{c}{$\begin{array}{c}\text { Clay } \\
\%\end{array}$} & $\begin{array}{c}\text { Organic C } \\
\%\end{array}$ & $\mathrm{pH}\left(\mathrm{H}_{2} \mathrm{O}\right)$ & $\left.\mathrm{Al}^{*}\right)$ & \multicolumn{2}{c}{$\left.\mathrm{Fe}^{*}\right)$} \\
\hline I: & Mean & 37 & 3.3 & 5.4 & 84 & 71 \\
& Range & $27-44$ & $2.6-4.0$ & $5.3-5.6$ & $71-100$ & $64-77$ \\
II: & Mean & 31 & 3.4 & 6.0 & 64 & 85 \\
& Range & $25-40$ & $2.1-5.1$ & $5.8-6.1$ & $52-86$ & $76-91$ \\
\hline
\end{tabular}

*) extracted with $0.05 \mathrm{M}$ ammonium oxalate at $\mathrm{pH} 3.3$. 
Table 2. Contents of phosphorus extracted with water $\left(\mathrm{P}_{\mathrm{w}}\right)$ or with an acid ammonium acetate solution $\left(\mathrm{P}_{\text {AMAc }}\right)$ from subsamples of two soils fertilized with different rates of P.*)

\begin{tabular}{|c|c|c|}
\hline $\begin{array}{l}\text { Fertilization } \\
\mathrm{kg} \mathrm{P} / \mathrm{ha} \\
\text { annually }\end{array}$ & $\begin{array}{c}P_{\text {AAAc }} \\
\mathrm{mg} / \mathrm{dm}^{3}\end{array}$ & $\begin{array}{c}P_{w} \\
\mathrm{mg} / \mathrm{kg}\end{array}$ \\
\hline & \multicolumn{2}{|c|}{ Soil I } \\
\hline 0 & $2.5^{b}$ & $2.5^{\mathrm{c}}$ \\
\hline $13 / 16$ & $3.4^{\mathrm{ab}}$ & $3.6^{c}$ \\
\hline $26 / 32$ & $4.8^{\mathrm{a}}$ & $5.1^{\mathrm{b}}$ \\
\hline $47 / 56$ & $5.0^{\mathrm{a}}$ & $7.3^{\mathrm{a}}$ \\
\hline \multirow[t]{2}{*}{$60 / 72$} & $5.0^{\mathrm{a}}$ & $5.5^{b}$ \\
\hline & \multicolumn{2}{|c|}{ Soil II } \\
\hline 0 & $3.7^{\mathrm{d}}$ & $5.1^{\mathrm{e}}$ \\
\hline $13 / 16$ & $4.7^{c}$ & $6.7^{\mathrm{d}}$ \\
\hline $26 / 32$ & $5.8^{\mathrm{bc}}$ & $9.4^{c}$ \\
\hline $47 / 56$ & $6.4^{b}$ & $12.3^{b}$ \\
\hline $60 / 72$ & $7.7^{\mathrm{a}}$ & $13.7^{\mathrm{a}}$ \\
\hline
\end{tabular}

*) The results of each soil and extraction have been tested separately. Means with a common letter are not different at the $95 \%$ level of statistical probability.

tion concentrations as milligrams per litre. The isotherms had the general formula of $y=b x+a$. The details of the interpretation of the isotherms have been presented by HARTIKAINEN (1982a).

Reversibly adsorbed $\mathrm{P}\left(\mathrm{P}_{\mathrm{i}}\right)$ was determined by a method in which $\mathrm{P}$ desorbing from the soil is trapped by strips of filter paper impregnated with freshly precipitated iron hydroxide (Zee et al. 1987, Yli-Halla 1989a). Phosphorus was also extracted with water (1:60, w/v) (HARTIKAINEN 1982a) and with an ammonium acetate solution $(0.5 \mathrm{M}$ ammonium acetate, 0.5 M acetic acid) at pH 4.65 (20:200, v/v) (VUORINEN and MÄKITIE 1955) (Table 2), the results of which have been published earlier (Yli-Halla 1989b).

\section{Results}

In the isotherm $\mathrm{A}$, the quantities of $\mathrm{P}$ adsorbed or desorbed are plotted against the initial concentration of $\mathrm{P}$ of the added solution. Based on this plotting, observations can be made about the effect of a given $\mathrm{P}$ addition, e.g. fertilization, on the quantities of $\mathbf{P}$ adsorbed or desorbed. The type A isotherms

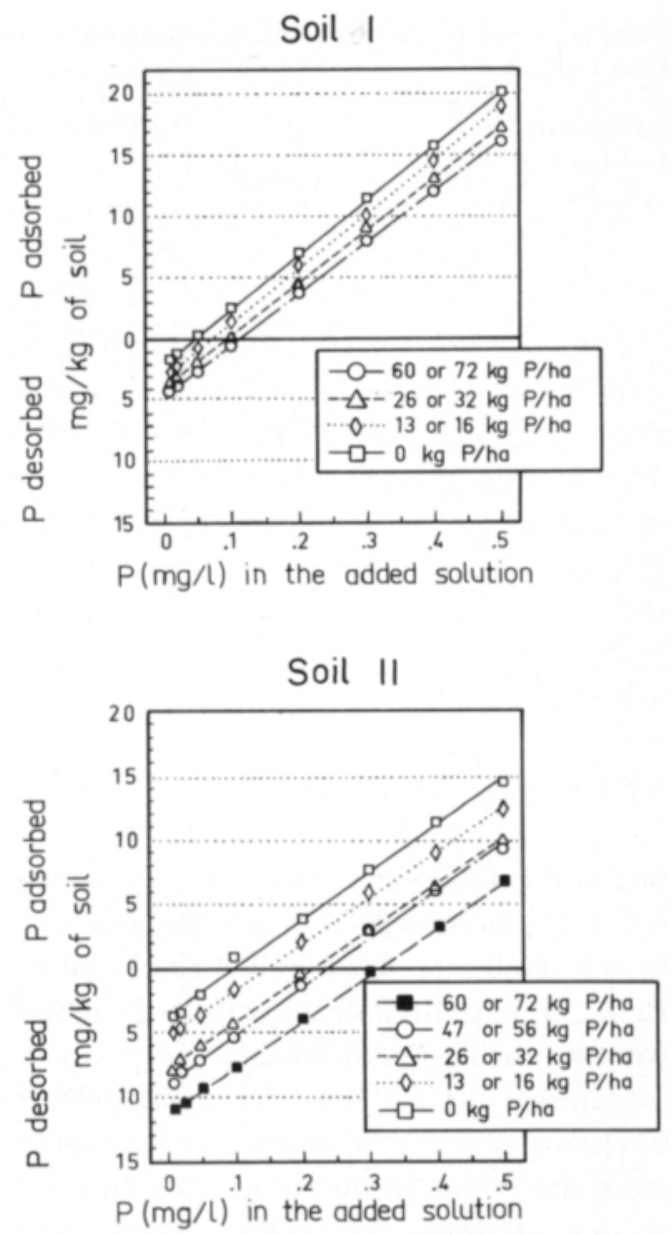

Fig. 1. Type A isotherms. Adsorption or desorption of phosphate (y) as a function of the concentration of added $\mathrm{P}$ solution ( $\mathrm{x}$ ) by subsamples of two soils (I and II) into which different rates of $P$ had been applied annually.

(Fig. 1) showed that the subsamples of soil I adsorbed $\mathrm{P}$ somewhat more effectively than did the ones of soil II. This can also be concluded from the larger coefficient $b$ in the equations of the A-type isotherms (Table 3). As an example, when the solution of $0.5 \mathrm{mg}$ $\mathrm{P} / 1$ was added ( $\mathrm{P}$ addition of $25 \mathrm{mg} \mathrm{P} / \mathrm{kg}$ ), the subsamples of soil II not fertilized with $\mathrm{P}$ adsorbed $14.8 \mathrm{mg} / \mathrm{kg}(59 \%)$ while as much as $20.2 \mathrm{mg} / \mathrm{kg}(81 \%)$ was adsorbed by the corrensponding subsample of soil I. From the same addition, $61 \%$ and $27 \%$ was adsorbed by the subsamples fertilized with the highest $\mathrm{P}$ rate in soils I and II, respectively. The subsample of soil I fertilized even with the highest 
Table 3. The equations of phosphate adsorption isotherms of subsamples of two soils receiving different rates of $P$ fertilization.

\begin{tabular}{|c|c|c|c|c|}
\hline \multirow{2}{*}{$\begin{array}{l}\text { Fertilization } \\
\mathrm{kg} \mathrm{P} / \mathrm{ha} \\
\text { annually }\end{array}$} & \multicolumn{2}{|c|}{ Soil I } & \multicolumn{2}{|c|}{ Soil II } \\
\hline & Equation & r & Equation & $\mathrm{r}$ \\
\hline & \multicolumn{4}{|c|}{ Isotherm A } \\
\hline 0 & $y=44.54 x-2.08$ & $0.999^{* * *}$ & $y=37.27 x-3.79$ & $0.998 * * *$ \\
\hline $13 / 16$ & $y=43.82 x-2.98$ & $0.999 * * *$ & $y=35.69 x-5.34$ & $0.999 * * *$ \\
\hline $26 / 32$ & $y=42.91 x-4.11$ & $0.999 * * *$ & $y=35.99 x-7.88$ & $0.999 * * *$ \\
\hline $47 / 56$ & $y=42.64 x-4.93$ & $0.998 * * *$ & $y=37.56 x-9.00$ & $0.998^{* * *}$ \\
\hline \multirow[t]{2}{*}{$60 / 72$} & $y=41.76 x-4.74$ & $0.999 * * *$ & $y=35.82 x-11.07$ & $0.999 * * *$ \\
\hline & \multicolumn{4}{|c|}{ Isotherm B } \\
\hline 0 & $y=404.35 x-18.91$ & $0.996 * * *$ & $y=124.65 x-13.13$ & $0.992 * * *$ \\
\hline $13 / 16$ & $y=379.61 x-27.22$ & $0.993 * * *$ & $y=106.13 x-16.00$ & $0.993^{* * *}$ \\
\hline $26 / 32$ & $y=297.11 x-28.54$ & $0.998 * * *$ & $y=111.11 x-24.60$ & $0.996^{* * *}$ \\
\hline $47 / 56$ & $y=267.45 x-29.10$ & $0.998 * * *$ & $y=123.39 x-30.10$ & $0.986^{* * *}$ \\
\hline $60 / 72$ & $y=249.87 x-28.25$ & $0.997 * * *$ & $y=109.65 x-34.07$ & $0.997 * * *$ \\
\hline
\end{tabular}

rate of $\mathrm{P}$ for 12 years adsorbed approximately equal quantities of $\mathrm{P}$ as did the subsample of soil II not fertilized with P for 11 years. In each soil, phosphate adsorption decreased with increasing $\mathrm{P}$ fertilization.

Isotherm B (Fig. 2) allows conclusions to be drawn about $\mathrm{P}$ sorption and desorption when the $\mathrm{P}$ concentration of soil solution is changed. The slope reflects the $\mathrm{P}$ buffer power of the soil. Soil I seemed to be more buffered against changes in equilibrium concentration than was soil II. In soil I there was a slight tendency of the buffer power to decrease with increasing $\mathbf{P}$ fertilization, while the change in soil II was inconsistent.

From isotherm $\mathrm{B}$, the quantity of $\mathrm{P}$ adsorption required for the elevation of solution $\mathrm{P}$ concentration to $0.2 \mathrm{mg} / \mathrm{l}$ was calculated (Table 4). This $P$ concentration has been regarded as being sufficient for maximum yield for most cultivated crops. The calculation demonstrated the greater tendency for $\mathrm{P}$ sorption of soil I. Inversely, the subsamples of soil II receiving the three highest rates of $\mathrm{P}$ maintained a solution concentration even higher than $0.2 \mathrm{mg} / \mathrm{l}$. Extrapolation to the lower concentrations is questionable because the isotherm is supposed to converge the y axis (HARTIKAINEN 1982b).
The equilibrium phosphate concentration (EPC) expresses the concentration at which no net exchange occurs between the soil and the surrounding solution. In soil I, EPC ranged from $0.05 \mathrm{mg} / 1$ to $0.11 \mathrm{mg} / \mathrm{l}$ (Table 5), while in soil II, the range was wider, i.e. from 0.11 to $0.31 \mathrm{mg} / \mathrm{l}$. According to the paired t-statistics, the subsamples of soil I maintained statistically significantly lower EPC values than did the ones of soil II at any level of P fertilization $\left(t=4.856^{* *}\right)$. The smaller changes in EPCs due to P fertilization in soil I, compared to the range of changes in soil II, were in agreement with the higher buffer power of soil I. However, it should be observed that the EPC values were consistently elevated upon increased $\mathrm{P}$ fertilization in both soils.

In order to find out the size of labile pool of $\mathrm{P}$, the quantity of reversibly adsorbed $\mathrm{P}$ $\left(\mathrm{P}_{\mathrm{i}}\right)$ was determined. In that method, $\mathrm{P}$ concentration is maintained at a very low level during the extraction due to removal of phosphate from the solution to the surface of a separate solid iron hydroxide phase, which promotes desorption. The quantity of $\mathrm{P}_{\mathrm{i}}$ (Table 5 ) was somewhat greater in the subsamples of soil II, as compared with the paired t-statistics with the corresponding samples of soil $\mathrm{I}(\mathrm{t}=$ $\left.3.557^{*}\right)$. 
Table 4. Quantities of P adsorbed (+) or desorbed (-) at equilibrium solution concentration of $0.2 \mathrm{mg} \mathrm{P} / 1$ in subsamples of two soils receiving different rates of $\mathrm{P}$ fertilization.

\begin{tabular}{|c|c|c|}
\hline \multirow[t]{2}{*}{$\begin{array}{l}\text { Fertilization } \\
\mathrm{kg} \mathrm{P} / \mathrm{ha} \\
\text { annually }\end{array}$} & \multicolumn{2}{|c|}{$\begin{array}{l}\mathrm{P} \text { adsorbed or desorbed }(\mathrm{mg} / \mathrm{kg}) \\
\text { at equilibrium concentration of } \\
0.2 \mathrm{mg} \mathrm{P} / 1\end{array}$} \\
\hline & Soil I & Soil II \\
\hline 0 & 62.0 & 11.8 \\
\hline $13 / 16$ & 48.7 & 5.2 \\
\hline $26 / 32$ & 27.3 & -2.4 \\
\hline $47 / 56$ & 24.4 & -5.4 \\
\hline $60 / 72$ & 21.7 & -12.1 \\
\hline
\end{tabular}

Table 5. Equilibrium phosphate concentration (EPC) and reversibly adsorbed $\mathrm{P}\left(\mathrm{P}_{\mathrm{i}}\right)$ in subsamples of two soils receiving different rates of $\mathrm{P}$ fertilization.*)

\begin{tabular}{|c|c|c|}
\hline $\begin{array}{l}\text { Fertilization } \\
\mathrm{kg} \mathrm{P} / \mathrm{ha} \\
\text { annually }\end{array}$ & $\begin{array}{l}\text { EPC } \\
\mathrm{mg} / 1\end{array}$ & $\begin{array}{c}P_{i} \\
\mathrm{mg} / \mathrm{kg}\end{array}$ \\
\hline & \multicolumn{2}{|c|}{ Soil I } \\
\hline 0 & $0.047^{b}$ & $16.8^{\mathrm{b}}$ \\
\hline $13 / 16$ & $0.072^{\mathrm{ab}}$ & $22.1^{\mathrm{ab}}$ \\
\hline $26 / 32$ & $0.096^{a}$ & $25.3^{\mathrm{ab}}$ \\
\hline $47 / 56$ & $0.112^{a}$ & $28.9^{\mathrm{a}}$ \\
\hline \multirow[t]{2}{*}{$60 / 72$} & $0.113^{\mathrm{a}}$ & $26.3^{\text {ab }}$ \\
\hline & \multicolumn{2}{|c|}{ Soil II } \\
\hline 0 & $0.105^{\mathrm{c}}$ & $21.8^{\mathrm{c}}$ \\
\hline $13 / 16$ & $0.151^{b c}$ & $26.1^{\mathrm{c}}$ \\
\hline $26 / 32$ & $0.221^{a b c}$ & $33.8^{\mathrm{b}}$ \\
\hline $47 / 56$ & $0.244^{\mathrm{ab}}$ & $38.3^{\mathrm{ab}}$ \\
\hline $60 / 72$ & $0.311^{\mathrm{a}}$ & $44.7^{a}$ \\
\hline
\end{tabular}

*) The results of EPC and $P_{i}$ have been tested separately within each soil. Means with a common letter are not different at the $95 \%$ level of statistical probability.

\section{Discussion}

The current measurements showed that soil I adsorbed $\mathrm{P}$ more effectively and had a higher $\mathrm{P}$ buffer power than soil II. Soil I was very much buffered, while soil II represented the average as compared with the clay soils of HaRTiKainen (1982c). During the last few years of the field experiments from which the soil samples originated, the highest yields in both soils were obtained at the fertilization level of $32 \mathrm{~kg} \mathrm{P} / \mathrm{ha}$ (YLI-HALla 1989b). The EPC values of the subsamples taken from these plots were approximately $0.1 \mathrm{mg} / 1$ and
Soil 1
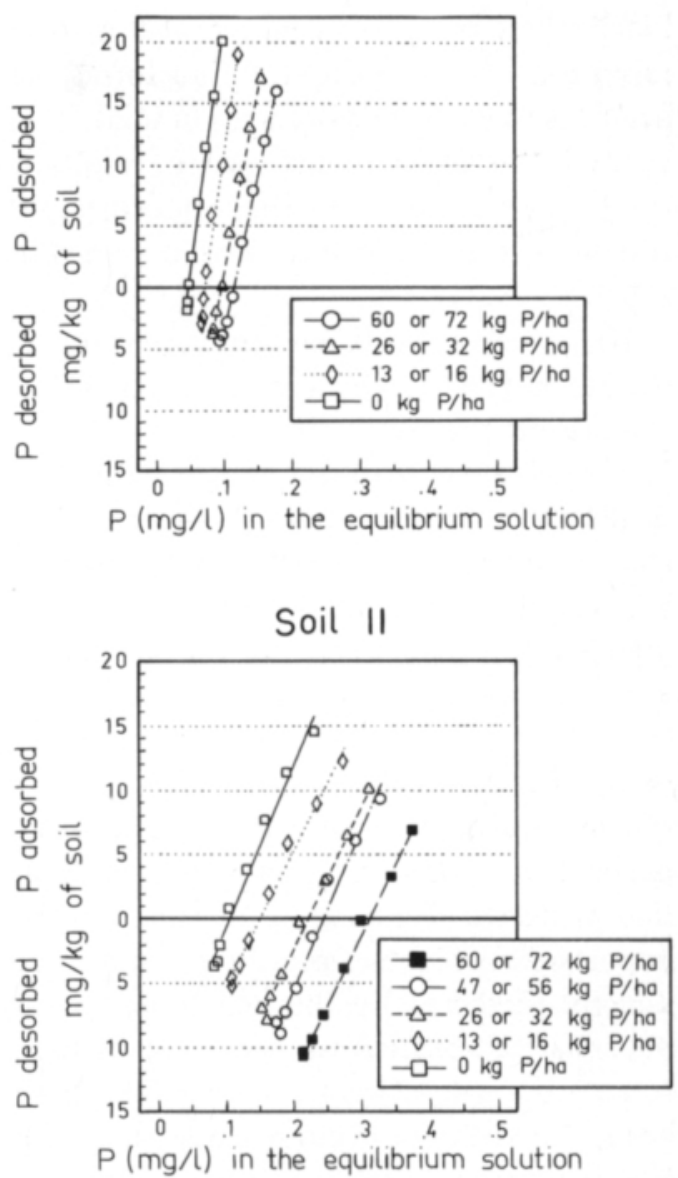

Fig. 2. Type B isotherms. Relationship between $\mathrm{P}$ adsorption or desorption (y) and the $\mathrm{P}$ concentration in the equilibrium solution $(\mathrm{x})$ after adding $\mathrm{P}$ to subsamples of two soils (I and II) into which different rates of $\mathrm{P}$ had been applied annually.

$0.2 \mathrm{mg} / 1$ in soils I and II, respectively, suggesting that a lower solution $\mathrm{P}$ concentration was sufficient for maximum yield in soil I. This is in accordance with the conclusion by Olsen and Watanabe (1970) that in soils of higher buffer power (soil I), a lower $\mathrm{P}$ concentration in the soil solution is needed for a given quantity of $\mathrm{P}$ uptake by plants. Thus, the lower EPC values in soil I do not as such imply poorer $\mathrm{P}$ supply to the plants in this soil. However, in addition to lower $\mathrm{P}$ intensities, reflected by the EPC values of the soil samples, the reserve of plant-available $\mathrm{P}$, as measured by the quantity of reversibly adsorbed $\mathrm{P}$, 
was lower in the subsamples of soil I. As combined, these two results suggest that a more rapid conversion of added $\mathrm{P}$ into forms not available to plants had occurred in soil I. This conclusion is in accordance with the results of the field experiments in which much larger responses to $\mathrm{P}$ fertilization were obtained in soil I.

There were a few differences in the properties of soil I and II which contribute to higher $\mathrm{P}$ adsorption in soil I: clay content ( $37 \%$ vs. $31 \%)$, pH (5.4 vs. 6.0) and oxalate-extractable $\mathrm{Al}(84 \mathrm{mmol} / \mathrm{kg}$ vs. $64 \mathrm{mmol} / \mathrm{kg})$. On the contrary, the content of oxalate-extractable Fe was greater in soil II $(71 \mathrm{mmol} / \mathrm{kg}$ vs. 85 $\mathrm{mmol} / \mathrm{kg}$ ). It is not likely that the differences in $\mathrm{P}$ adsorption characteristics as well as longterm effect of $\mathrm{P}$ fertilization can completely be attributed to these minor differences.

The residual effect of $\mathrm{P}$ fertilization is dependent on the rate of slow long-term fixation processes occurring in the soil, and the importance of these processes cannot be directly predicted by the determination of phosphate adsorption isotherms. Short-term $P$ adsorption by 24 soils of Australia have been observed to be in close relationship with $\mathrm{P}$ sorption also in the long run and in positive correlation with the yield response by clover to $\mathrm{P}$ fertilization in a pot experiment (BARrow 1972). In Sweden, StȦHLbERg (1982) even suggested a method based on the determination of $\mathrm{P}$ adsorption for the basis for $\mathrm{P}$ fertilization recommendations. HoLFORD (1982) further showed that the recovery of fertilizer $\mathrm{P}$ over a period of four years in a pot experiment was in close correlation with the results of short-term P adsorption measurements. Also in the present study, there seemed to be a relationship between the yield response to $\mathrm{P}$ fertilization and $\mathrm{P}$ adsorption by the soil. Even though the current material consisted of samples taken only from two field experiments, the observed tendency is likely not a coincidence, because it is well in agreement with the results of other studies mentioned above. The results of the present study thus confirm that short-term $\mathrm{P}$ adsorption measurements are indeed able to serve as a valuable tool in practical soil fertility research in elucidating the tendency of adsorption of added $\mathrm{P}$ as well as the probable long-term yield response to $\mathrm{P}$ fertilization.

Previous results (YLI-Halla 1989b) showed that repeated $\mathrm{P}$ fertilization for 11 or 12 years had a different effect on the quantities of easily soluble $\mathrm{P}$ in the two soils studied despite the originally same $\mathrm{P}$ status of soils. It should be recognized that water extraction was in the present soils more accurate in reflecting the residual effect of $P$ fertilization. The present results further showed that the changes in equilibrium phosphate concentration (EPC), attributable to $\mathrm{P}$ fertilization, differed widely from soil to soil. The difference between the two soils could not be predicted from soil properties other than P sorption. Even though it is not possible by the results of ordinary acetate or water extraction to predict the residual effect of $\mathrm{P}$ fertilization, regular soil analysis is of utmost importance in monitoring the cumulative effect of P status of the soil. By knowing the quantities of $\mathrm{P}$ fertilization given and the consequent changes in soil testing results, the farmer is gradually able to get a sound idea of the residual effect of $\mathrm{P}$ fertilization in the field concerned. 


\section{References}

ANON. 1969. Juoma- ja talousveden tutkimusmenetelmăt. Elintarviketutkijain Seura. 169 p. Helsinki.

BARROW, N.J. 1972. Relationship between a soil's ability to adsorb phosphate and the residual effectiveness of superphosphate. Aust. J. Soil Res. 11: 57-63.

Hartikainen, H. 1982a. Water soluble phosphorus in Finnish mineral soils and its dependence on soil properties. J. Scient. Agric. Soc. Finl. 54: 89-98.

- 1982b. Relationship between phosphorus intensity and capacity parameters in Finnish mineral soils. I. Interpretation and application of phosphorus sorption -desorption isotherms. J. Scient. Agric. Soc. Finl. 54: 245-250

- 1982c. II. Sorption-desorption isotherms and their relation to soil characteristics. J. Scient. Agric. Soc. Finl. 54: 251-262.

Holford, I.C.R. 1982. Effects of phosphate sorptivity on long-term plant recovery and effectiveness of fertilizer phosphate in soils. Plant and Soil 64: 225-236.

Larsen, S., Gunary, D. \& Sutton, C.D. 1965. The rate of immobilization of applied phosphate in relation to soil properties. Plant and Soil 16: 141-148.

Olsen, S.R. \& Watanabe, F.S. 1970. Diffusive supply of phosphorus in relation to soil texture variations. Soil Sci. 110: 318-327.

StȦhl一erg, S. 1982. A fixation method for estimation of the $\mathrm{P}$ requirement of soils. Acta Agric. Scand. 32: 3-11.

SipPola, J. \& SAarela, I. 1986. Some extraction methods as indicators of need for phosphorus fertilization. Ann. Agric. Fenn. 25: 265-271.

VUorınen, M. \& MÃKıтIE, O. 1955. The method of soil testing in use in Finland. Agrogeol. Publ. 63. 44 p. Helsinki.

YLI-Halla, M. 1989a. Reversibly adsorbed P in mineral soils of Finland. Commun. Soil Sci. Plant Anal. 20: 695-709.

- 1989b. Effect of different rates of $\mathrm{P}$ fertilization on the yield and $\mathbf{P}$ status of the soil in two long-term field experiments. J. Agric. Sci. Finl. 61: 361-370.

ZeE, S.E.A.T.M. van der, FoKkinK, L.G.T. \& RiEMSDIJK, W.H. van. 1987. A new technique for assessment of reversibly adsorbed phosphate. Soil Sci. Soc. Amer. J. 51: 599-604.

Ms received February 12, 1991

\section{SELOSTUS}

\section{Fosforin pidättyminen kahdesta pitkäaikaisesta fosforilannoituskokeesta otettuihin maanäytteisiin}

\author{
Markku Yli-Halla
}

Kemira Oy, Espoon tutkimuskeskus, Luoteisrinne 2, 02270 ESPOO

Tutkimusta varten otettiin maanäytteitä kenttäkokeista, joissa oli 11 tai 12 vuoden ajan ollut viisi eri P-lannoitustasoa (vuosittain 0,13 tai 16, 26 tai 32, 47 tai 56 sekả 60 tai $72 \mathrm{~kg} \mathrm{P} / \mathrm{ha}$ ). Kokeet olivat hiuesavimailla, ja niissă oli aluksi samat määrăt happamaan ammoniumasetaattiliuokseen uuttuvaa fosforia (n. $6 \mathrm{mg} / \mathrm{l}$ ), ja niiden ominaisuudet olivat muutenkin lähes samanlaiset. Kuitenkin toisessa maassa (maa I) P-lannoitus lisäsi satoa paljon enemmăn kuin toisessa (maa II). Kun kenttăkokeiden päăttyessă otettujen maanăytteiden fosforinpidătyskykyả tutkittiin ravistelemalla maanäytteită $(1 \mathrm{~g})$ eri vahvuisissa $(0-0.5 \mathrm{mg} / \mathrm{l})$ fosforiliuoksissa, havaittiin, että maan I năytteet pidăttivăt fosforia huomattavasti tehokkaam- min kuin maan II năytteet. Myös labiilin fosforin kokonaismäärä oli maan I näytteissä pienempi kuin maan II vastaavan lannoituksen saaneissa näytteissä. Selitys maalla I P-lannoituksella kenttăkokeissa saatuihin suuriin sadonlisäyksiin oli siis se, että tässä maassa lannoitefosfori pidăttyi nopeasti kasveille käyttökelvottomaan muotoon, kun taas maassa II lannoitefosfori säilyi suuremmassa määrin liukoisena. Koska nykyisin maa-analyysimenetelmin ei pystytä luotettavasti arvioimaan P-lannoituksen jälkivaikutuksen suuruutta maan ominaisuuksien perusteella, on viljavuusanalyysi tehtävä kyllin usein maan Ptilan kehityksen seuraamiseksi. 